\title{
Shaft Furnace Sintering Temperature Homogenization by the Coke Charging
}

\author{
J. GLOČEK, D. Naščák \& P. Palička
}

Development and realization workplace of raw materials extracting and treatment, Technical University of Kosice, Němcovej 32, 04384 Košice, Slovakia

ABSTRACT: In terms of specific energy consumption, heat treatment of magnesite in shaft furnaces is a very difficult process allowing reaches the desired characteristics of processed magnesite substances only in increased energy consumption. The main reason is nonuniformity of sintering temperatures in the cross section of the shaft furnace. The lowest sintering temperature is achieved in the centre of the furnace. The reason is that no fuel is directly given to the middle of the furnace due to potential flow and transfer of heat from the surrounding layers is very limited. The new concept is based on the use of coke charged to the central part of the furnace. The considerable balancing of the maximum temperature is reached by combustion of coke by secondary air passing through the central part of the furnace. The results of experiments confirmed the possibility of using coke, achieving a substantial improvement in the shaft furnace work.

KEYWORD: shaft furnace; magnesite; sintering; calcinations; coke; clinker

\section{INTRODUCTION}

The raw magnesite reached in SMZ, a.s. Jelsava is used to produce sintered magnesia or caustic magnesite, i.e. magnesium oxide - periclase with iron oxide, calcium oxide and silicon oxide, contained in the relevant mineral forms (Košinár 2011). The basic products of processing magnesite of all manufacturing companies are:

- sintered (dead-burnt) magnesia,

- caustic calcined magnesia,

- partially calcined magnesite (Koštial 2012)

Refractory magnesia products are applied in the production and processing of metals, especially steel, such as furnace linings and containers used for operating iron slags at high temperatures. Magnesite $\left(\mathrm{MgCO}_{3}\right)$ is decomposed into $\mathrm{MgO}$ and $\mathrm{CO}_{2}$ by heat treatment at temperature of $399^{\circ} \mathrm{C}$. Magnesite begins to be unstable from temperature of about $250^{\circ} \mathrm{C}$ for the presence of $\mathrm{CO}_{2}$ in the atmosphere. For $\mathrm{CaCO}_{3}$ are responsible temperatures $883 / 537^{\circ} \mathrm{C}$. Both processes are endothermic (Repiský \& Vikorová 2008).

$\mathrm{MgCO}_{3}(\mathrm{~s})=\mathrm{MgO}(\mathrm{s})+\mathrm{CO}_{2}(\mathrm{~g}) \Delta \mathrm{H}=121,0 \mathrm{~kJ} \cdot \mathrm{mol}^{-1}$ $(298 \mathrm{~K}) 93,9 \mathrm{~kJ} \cdot \mathrm{mol}^{-1}(893 \mathrm{~K})$

$\mathrm{CaCO}_{3}(\mathrm{~s})=\mathrm{CaO}(\mathrm{s})+\mathrm{CO}_{2}(\mathrm{~g}) \Delta \mathrm{H}=178,4 \mathrm{~kJ} \cdot \mathrm{mol}^{-1}$ $(298 \mathrm{~K}) \quad 166,0 \mathrm{~kJ} \cdot \mathrm{mol}^{-1}(1173 \mathrm{~K})$

\subsection{Shaft furnace}

Crucial aggregates for the production of sintered and caustic magnesia for the company SMZ, a.s. Jelšava are rotary and shaft furnaces. Burden of the shaft furnaces consists of raw material with 40 to $150 \mathrm{~mm}$ grain size and concentrates with grain size from 40 to $100 \mathrm{~mm}$ charged in a ratio of $67 \%$ : $33 \%$. In terms of chemical composition, quality standard of two basic types of burden for the shaft furnaces is given in Table 1 (Košinár 2011).

Table 1. Charge parameters for shaft furnaces.

\begin{tabular}{|c|c|c|c|c|}
\hline & min. \% & \multicolumn{3}{|c|}{ max. \% } \\
\hline SF charge & MgO & $\mathbf{C a O}$ & $\mathbf{F e}_{\mathbf{2}} \mathbf{O}_{\mathbf{3}}$ & $\mathbf{S i O}_{\mathbf{2}}$ \\
\hline $\mathrm{S} 40-150 \mathrm{~mm}$ & 42 & 3 & 3,8 & 0,5 \\
\hline $\mathrm{K} 140-100 \mathrm{~mm}$ & 43,5 & 2,4 & 3,9 & 0,4 \\
\hline
\end{tabular}

Shaft furnace as countercurrent thermal aggregate is technically divided into 4 zones:

- drying and preheater- 2 - $3 \mathrm{~m}$ - burden heating to $350-600^{\circ} \mathrm{C}$,

- decarbonization - high $2-4 \mathrm{~m}$, at material temperature $600-1200^{\circ} \mathrm{C}$,

- sintering - high $2-3 \mathrm{~m}$, periclase formation and sintering at temperature $1500-1700^{\circ} \mathrm{C}$,

- cooling - high 4-6m - stabilization of the structure of fired clinker and its cooling by air to temperature of $700-800{ }^{\circ} \mathrm{C}$ (Koštial \& Benčo 2012, Varga 1999). 
Processing of raw magnesite in the shaft furnace consists of four basic operations technological:

- drying,

- calcination or decarbonization,

- sintering,

- cooling.

A major problem of the current shaft furnaces at magnesite thermal treatment is temperatures inhomogeneity in cross section of the furnace. Course of maximum temperature in radius of shaft furnace is shown in Figure 1.

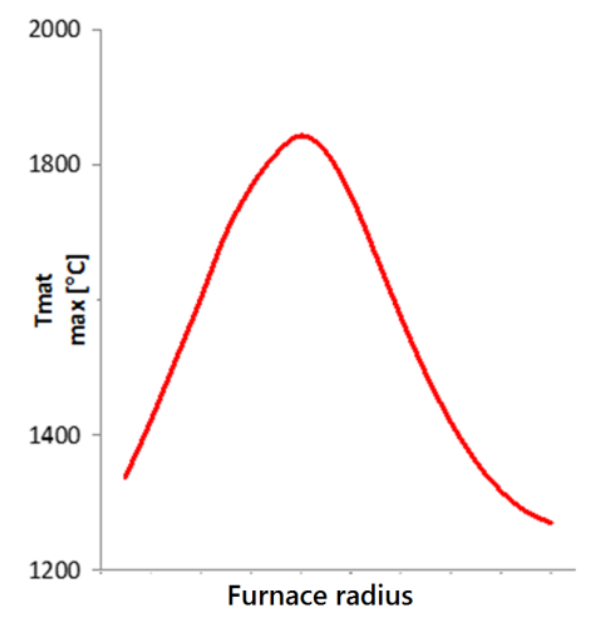

Figure 1. Course of maximum temperature in radius of shaft furnace.

The maximum of the course of temperature in radius of workspace of the furnace is close to the working lining and the minimum is in the centre of shaft furnace (thermal field inhomogeneity in the cross section of the furnace).

The furnace with power of $2.5 \mathrm{t} / \mathrm{h}$ for calcination of magnesite is shown in Figure 2.

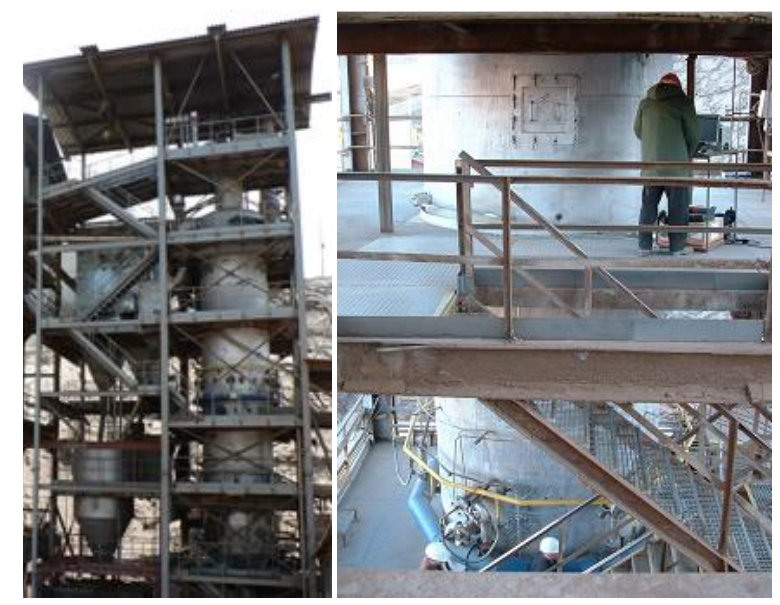

Figure 2. Shaft furnace for magnesite firing - a general view and detail of the furnace.

Shaft furnace consists of a steel shell of thickness $20-30 \mathrm{~mm}$ that surrounds the refractory lining. At the bottom of the furnace is placed Gruber grade. Heat generation is provided by 6 burners which are shifted by $60^{\circ}$. At a distance of $1000 \mathrm{~mm}$ below the bottom burners are three sampling openings forming angles of $120^{\circ} \mathrm{C}$. The furnace has a telescopic hopper on its top through which the charging is provided. Between the bell and the furnace shell is the area without lining, from which flue gases are exhausted. The furnace is closed by top furnace. The flue gases are exhausted from the furnace space to the cyclone separators by pull fan or to the JET filter by own pull fan.

\section{CHARGING OF CALCINED ANTHRACITE}

The solution regarding a reduction in the size of the difference between $T_{\max }$ and $T_{\min }$ is carried out by supplying of an appropriate technological fuel to the axis of the shaft furnace. It is necessary to provide sufficient supply of combustion air and burning in height suitable for the settlement of the temperature profile in the sintering furnace space.

\subsection{Theoretical basis}

It is clear that the uniformity of the sintering quality of the charged material depends on the uniformity of temperature in the cross section of the sintering zone. Combustion of natural gas to the all volume of shaft furnace is complicated process due to weaker intersection of technological fuel of the burden as well as worst conditions for the good contact or due to mixing of combustion natural gas and oxygen contained in the primary or secondary air. Increasing the minimum value of the temperature in the middle of shaft furnace is possible to carry out by additional supplying and combustion of suitable technological fuel in the axis of the shaft furnace workspace. The fuel and the creation of such conditions used for burning in the shaft furnace sintering section are an important condition for the success of this solution.

\subsection{Technical solution}

Calcined anthracite of the appropriate grain size composition is considered as an appropriate additional fuel to ensure an increase in $T_{\min }$ in the shaft furnace axis in the sintering zone area.

Description of the used calcined anthracite is given in Table 2.

Table 2. Change of supplied heat

\begin{tabular}{|l|l|}
\hline Content of $\mathrm{C}$ & $\min .93,5 \%$ \\
\hline Ash content & $\max .5,0 \%$ \\
\hline $\mathrm{H}_{2} \mathrm{O}$ content & $\max .0,5 \%$ \\
\hline sulfur content & $\max .0,8 \%$ \\
\hline Combustible volatile content & $\max .0,7 \%$ \\
\hline Grain & $12-30 \mathrm{~mm}$ \\
\hline
\end{tabular}

Charging was implemented by method shown in Figure 3, 4. 


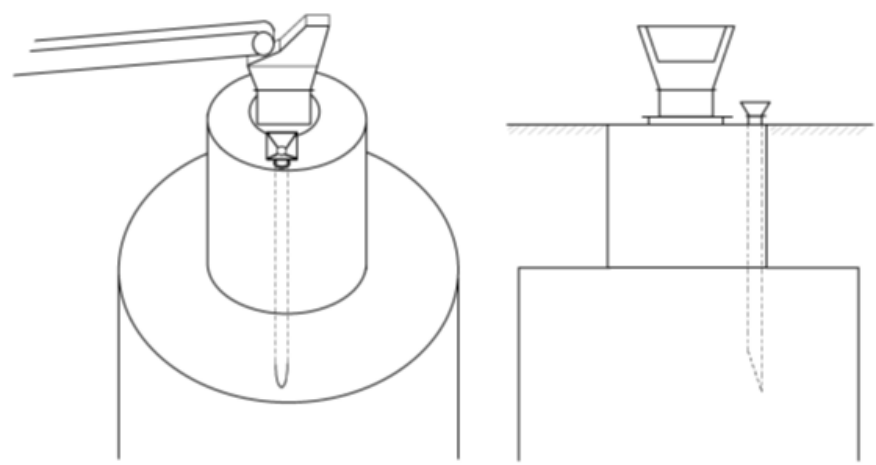

Figure 3. Schematic depiction of the method of additional fuel dosing.

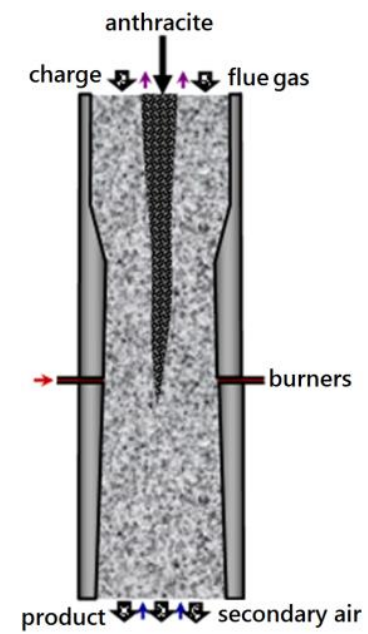

Figure 4. Shaft furnace charging scheme.

An important prerequisite for obtaining the required $\mathrm{T}_{\min }$ in central of shaft furnace was to ensure supply of a fixed quantity of calcined anthracite. Movement of anthracite was verified on physical 2D model (see Figure 7). Required diameter of a charging pipe was calculated based on the rate of charge movement in the upper part of furnace and on the calcined anthracite density.
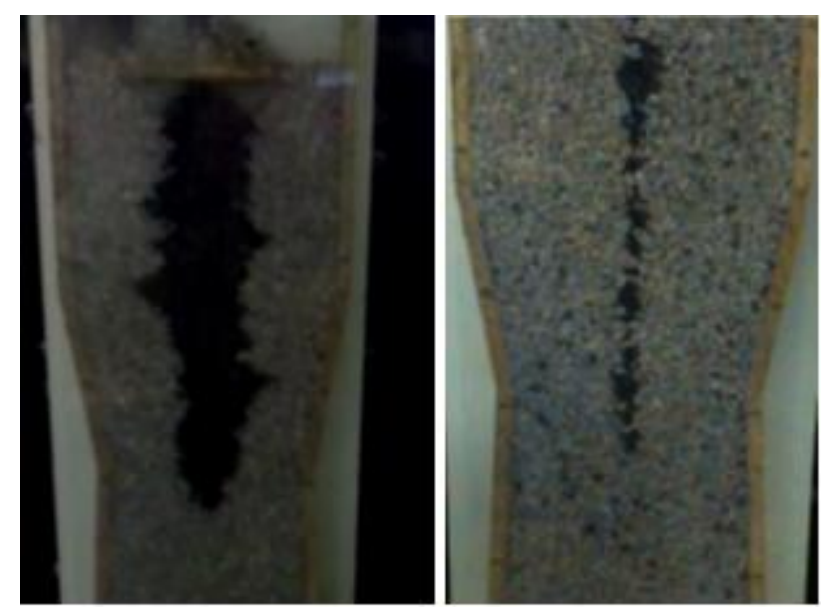

Figure 5. Physical 2D model of shaft furnace.

Calculations were provided considering refund of $20 \%$ amount of natural gas by anthracite. Supplied heat change over use of natural gas by anthracite combustion in presented in Table 3.
Table 3. Supplied heat change

\begin{tabular}{|l|l|l|}
\hline Volume of natural gas & 360 & $\mathrm{~m}^{3} / \mathrm{h}$ \\
\hline Calorific value of natural gas & 34 & $\mathrm{MJ} / \mathrm{m}^{3}$ \\
\hline Supplied heat by natural gas & 12,24 & $\mathrm{GJ} / \mathrm{h}$ \\
\hline Volume of anthracite & 83,3 & $\mathrm{~kg} / \mathrm{h}$ \\
\hline Calorific value of anthracite & 26 & $\mathrm{MJ} / \mathrm{kg}$ \\
\hline Supplied heat by anthracite combustion & 2,17 & $\mathrm{GJ} / \mathrm{h}$ \\
\hline Supplied heat increase & $\mathbf{1 7 , 7}$ & $\mathbf{\%}$ \\
\hline Amount of burned air by anthracite combustion & $\mathbf{7 3 9 , 8}$ & $\mathrm{m}^{3} / \mathrm{h}$ \\
\hline
\end{tabular}

\subsection{Mathematical simulation}

Selected alternatives of anthracite charging using mathematical model (Koštial 2013) based on elementary balances method were validated by simulation. Results of simulations are presented on the Figure $6-8$.

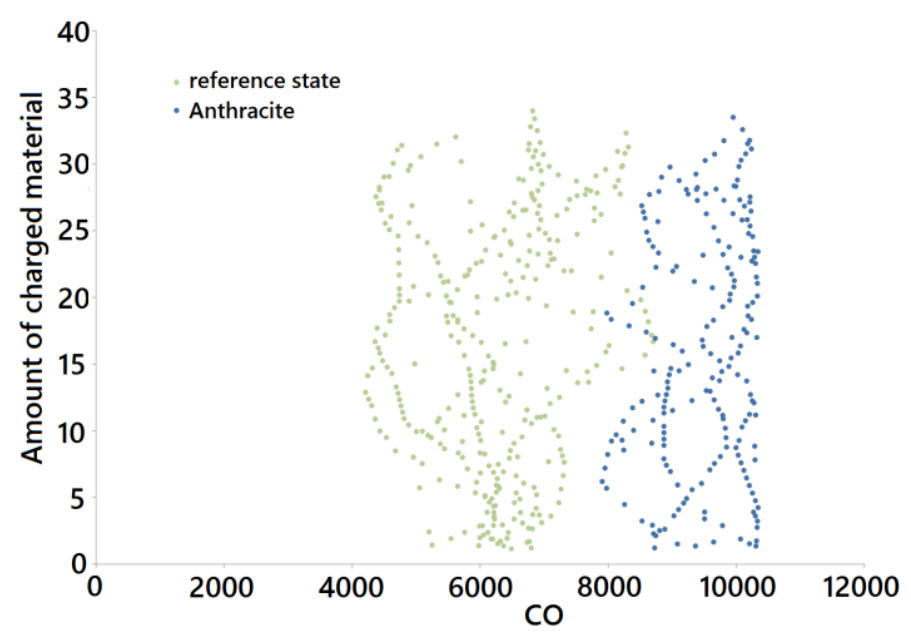

Figure 6. CO ratio change over the charged material.

Change of $\mathrm{CO}$ amount at reference state and during charging of anthracite is presented on the Figure 7. As one can see there is a slight increase of $\mathrm{CO}$ in the flue gas which indicates worse use of supplied heat however this does not exclude increase $\mathrm{f}$ temperature field homogeneity in the furnace cross section.

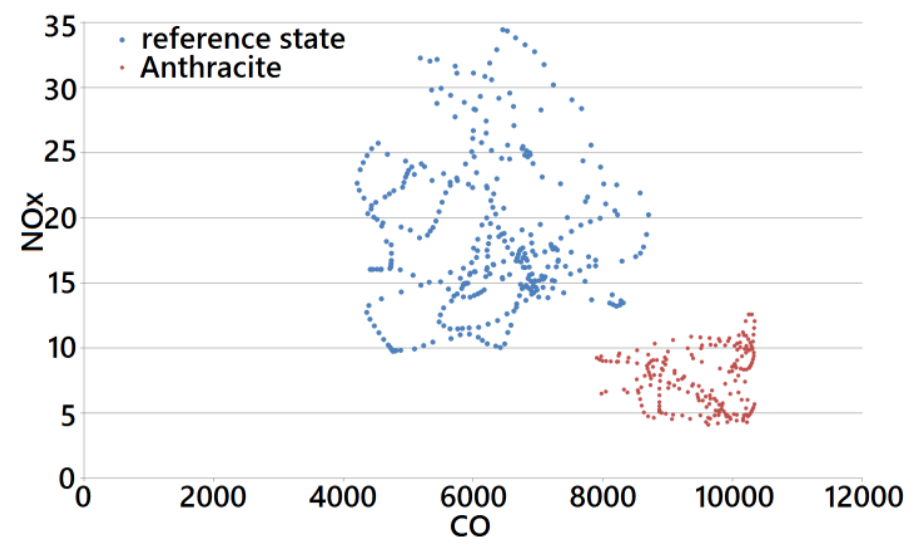

Figure 7. Ratio change of $\mathrm{NO}_{\mathrm{x}}$ and $\mathrm{CO}$.

Reduction of $\mathrm{NO}_{\mathrm{x}}$ in the flue gas is explained by the extreme decrease of the maximum temperature 
in the furnace (which evolves a greater volume of $\mathrm{NO}_{\mathrm{x}}$ ), and by the unused secondary air decreasing.

Movement of anthracite charging was verified on a physical model at scale 1:10 (Figure 5). The selected variants of anthracite use as a required supplemental fuel have been simulated using mathematical model. The results are shown in the Table 4 and in Figure 8.

Table 4. Mathematical simulation data.

\begin{tabular}{|c|c|c|c|c|c|c|}
\hline \multicolumn{2}{|c|}{ Alternative } & 1 & 2 & 3 & 4 & 5 \\
\hline \multicolumn{2}{|c|}{ Product $[\mathrm{kg} / \mathrm{h}]$} & 4750 & 4750 & 5000 & 5000 & 4750 \\
\hline \multirow{3}{*}{ Batch } & $\begin{array}{c}\text { Anthracite } \\
{[\%]}\end{array}$ & 3 & 3 & 3 & 5 & 4 \\
\hline & $\begin{array}{c}\text { Magnesite } \\
{[\mathrm{kg} / \mathrm{h}]}\end{array}$ & 6790 & 6790 & 7275 & 7125 & 6720 \\
\hline & $\begin{array}{c}\text { Anthracite } \\
{[\mathrm{kg} / \mathrm{h}]}\end{array}$ & 210 & 290 & 225 & 375 & 280 \\
\hline \multicolumn{2}{|c|}{ Natural $\left[\mathrm{m}^{3} / \mathrm{h}\right]$} & 330 & 360 & 360 & 360 & 360 \\
\hline \multicolumn{2}{|c|}{ Primary air $\left[\mathrm{m}^{3} / \mathrm{h}\right]$} & 3400 & 3700 & 3700 & 3700 & 3700 \\
\hline
\end{tabular}

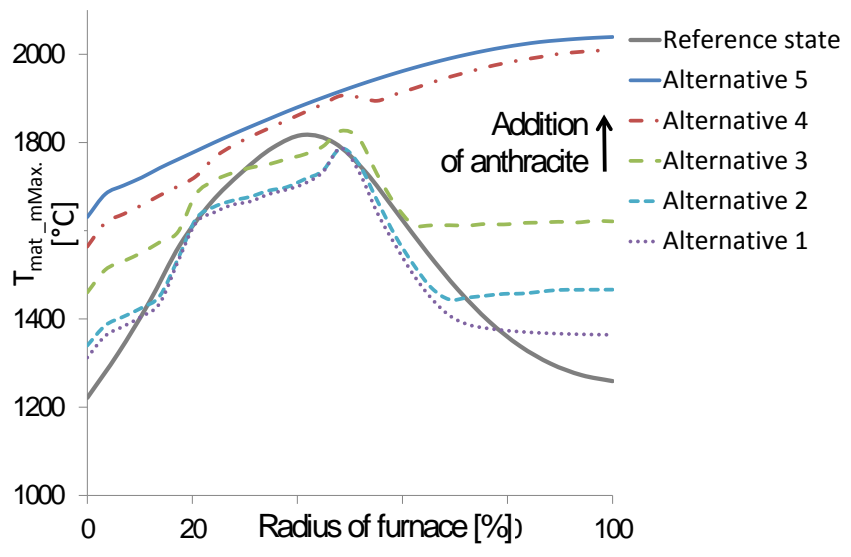

Figure 8. Anthracite combustion influence on temperature homogeneity over shaft furnace cross section.

\section{CONCLUSION}

This technical solution solves serious problem of temperature inhomogeneity over the furnace cross section resulting in negative impact on quality of produced clinker and need for sintering time extension of produced clinker. Combustion of anthracite in central of shaft furnace enables to use large amount of freely passing secondary air. This will limit the total, yet practically $100 \%$ overage of secondary air in the shaft furnace, thereby avoiding the energy losses in the heating and heat from fuel combustion technology could be used for sintered magnesia production.

\section{ACKNOWLEDGEMENTS}

This contribution/publication is the result of the project implementation Advanced technology for the mining company of 21 st century supported by the Research \& Development Operational Programme funded by the ERDF. (ITMS: 26220220131)

\section{REFERENCES}

[1] Kostial, I., et al. 2008. Advanced process manipulation of magnesia sintering. In.: Seoul, Korea, Proceedings of the 17th World Congress, The International Federation of Automatic Control: 718-723.

[2] Koštial, I. et al 2012. Low granulometry waste production decreasing in magnesite processing and new technologies for their processing. In Waste Forum 2: 91-97.

[3] Koštial, I. et al 2013. Simulation mathematical model for granular material thermal treatment. In Poland, 14th International Carpathian Control Conference: 150-153.

[4] Košinár, P. et al. 2011. Praxes needs in the area of research and development in SMZ, a.s. Jelšava, In Hrádok at Jelšava, Advance technologies of raw material mining and threatment: 228-232.

[5] Košinár, P. \& Benčo, G., 2012. Shaft furnace for clinker production for lower granulometry charge (experimental shaft furnace). In: Hrádok pri Jelšave, Košice, Advanced technologies in area of gaining and treatment of earth sources: 51-59.

[6] Repiský R. \& Vikorová, D. 2008. Project Mineralurg. Revúca: SMZ a. s. Jelšava, ZSOŠ.

[7] Varga, A. 1999. Thermal technique in metallurgy. Košice: HF TU in Košice. 